\title{
BENCH- AND PUOT-SCALE DEMONSTRATION OF THERMAL DESORPTION FOR REMOVAL OF MERCURY FROM THE LOWER EAST FORK POPLAR CREEK FLOODPLAIN SOILS
}

\author{
M. I. Morris, R. J. Sams, G. Gillis \\ R. W. Helsel, E. S. Alperin, T. J. Geisler, A. Groen, D. Root
}

\section{DISCLAIMER}

\begin{abstract}
This report was prepared as an account of work sponsored by an agency of the United States Government. Neither the United States Government nor any agency thereof, nor any of their employees, makes any warranty, express or implied, or assumes any legal liability or responsibility for the accuracy, completeness, or usefulness of any information, apparatus, product, or process disclosed, or represents that its use would not infringe privately owned rights. Reference herein to any specific commercial product, process, or service by trade name, trademark, manufacturer, or otherwise does not necessarily constitute or imply its endorsement, recommendation, or favoring by the United States Government or any agency thereof. The views and opinions of authors expressed herein do not necessarily state or reflect those of the United States Government or any agency thereof.
\end{abstract}

"The submitted manuscript has been authored by a contractor of the U.S. Government under contract No. DE-AC05-84OR21400. Accordingly, the U.S. Government retains a nonexclusive, royalty-free license to publish or reproduce the published form of this contribution, or allow others to do so, for U.S. Government purposes."

Oak Ridge National Laboratory

Oak Ridge, Tennessee 37831-6495

managed by

MARTIN MARIETTA ENERGY SYSTEMS, INC.

for the

U.S. DEPARTMENT OF ENERGY

under contract

DE-AC05-84OR21400 


\section{DISCLAIMER}

Portions of this document may be illegible in electronic image products. Images are produced from the best available original document. 


\title{
BENCH- AND PILOT-SCALE DEMONSTRATION OF THERMAL DESORPTION FOR REMOVAL OF MERCURY FROM THE LOWER EAST FORK POPLAR CREEK FLOODPLAIN SOILS
}

\author{
M.I. Morris, Oak Ridge National Laboratory, 'P. O. Box 2008, MS-6495, Oak Ridge, TN 37831-6495 \\ R.J. Sams, G. Gillis, Oak Ridge Y-12 Plant,' P. O. Box 2009, Oak Ridge, TN 37831-8174 \\ R.W. Helsel, E.S. Alperin, T.J. Geisler, A. Groen, D. Root, IT Corporation, Knoxville, Tennessee.
}

\begin{abstract}
Thermal desorption is an innovative technology that has seen significant growth in applications to organically contaminated soils and sludges for the remediation of hazardous, radioactive and mixed waste sites. This paper will present the results of a bench- and pilot-scale demonstration of this technology for the removal of mercury from the Lower East Fork Poplar Creek floodplain soil. Results demonstrate that the mercury in this soil can be successfully removed to the target treatment levels of 10 milligrams per kilogram $(\mathrm{mg} / \mathrm{kg})$ and that all process residuals could be rendered RCRA-nonhazardous as defined by the Resource Conservation and Recovery Act. Sampling and analyses of the desorber off-gas before and after the air pollution control system demonstrated effective collection of mercury and organic constituents. Pilot-scale testing was also conducted to verify requirements for material handling of soil into and out of the process.
\end{abstract}

This paper will also present a conceptual design and preliminary costs of a full-scale system, including feed preparation, thermal treatment, and residuals handling for the soil.

\section{INTRODUCTION}

Thermal desorption is being considered by the U.S. Department of Energy (DOE) as a potential treatment process for floodplain soils from the Lower East Fork Poplar Creek (LEFPC), a tributary which drains the Y-12 site in Oak Ridge, Tennessee. The LEFPC soils are being addressed under the Comprehensive Environmental Response, Compensation, and Liability Act (CERCLA); the teclnology demonstration was in support of the feasibility study to select an appropriate remedy. Successful treatment would provide the opportunity for considering replacement at the site.

Thermal desorption is a low to moderate temperature separation process that removes contaminants from soil and other solids. It has been proven on a wide variety of organic chemicals, including polynuclear aromatic hydrocarbons (PAH), polychlorinated biphenyls (PCB), chlorinated pesticides, and others having low volatility(1). The technology can also be applied to solids containing mercury, due to mercury's relatively high vapor pressure, although experience in this application has been very limited. Thermal desorption consists of an indirectly heated desorber unit and an off-gas treatment system, which collects the volatilized contaminants and water from the soil using condensation, scrubbing, adsorption and other conventional control devices. For treatment of mixed waste, thermal desorption offers the ability to separate the hazardous chemicals (RCRA) or toxic constituents (Toxic Substances Control Act [TSCA]) from the radioactive constituents, which remain in the bulk solids(2).

Based on the positive results of bench-scale treatability testing(3), Martin Marietta Energy Systems subcontracted with IT Corporation (IT) to conduct pilot-scale thermal desorption demonstration tests. The scope of work was to evaluate the various major process components of a complete treatment facility through a test program that confirmed that cleanup goals could be achieved, determined that desorbed contaminants could be effectively collected/controlled, and provided key scale-up data for preparing a conceptual full-scale design and cost estimate.

\footnotetext{
* Managed by Martin Marietta Energy Systems, Inc. for the U.S. Department of Energy under contract No. DE-AC05 840R21400.
} 


\section{SOIL CHARACTERISTICS}

LEFPC soil was excavated by hand from an area that had been identified during extensive site assessment to have the highest concentration of mercury(3). Ten drums of soil were shipped to IT's Environmental Technology Development Center in Oak Ridge, Tennessee. The soil was prepared for testing and analysis by sieving to remove oversize material, partial air drying, and thorough manual blending. This preparation is routinely done for treatability tests to ensure a uniform feed material for all testing, and to achieve material handling characteristics suitable for the pilot desorber system.

Chemical analysis included selected metals, volatile and semivolatile organics, and PCBs. Mercury concentration of the composite sample was $283 \mathrm{mg} / \mathrm{kg}$. Eight grab samples were analyzed for mercury to show that the soil was well homogenized; the relative standard deviation was 11 percent. Trace levels of various PAHs were identified; these were the only semivolatile organic compounds (SVOC) detected. Arochlor- 1260 was the only PCB detected. No volatile organic compounds (VOC) were detected. Total activity was $1.5 \mathrm{E}-4$ microcuries/gram and total uranium of 48 picocuries/gram. The total organic carbon (TOC) value for the soil was 4.7 percent.

Physical properties were also measured since these affect materials handling as well as thermal processing. The prepared soil particle size distribution showed approximately 60 percent silt, 20 percent clay (less than 2 micron), and 20 percent fine sand. The moisture content of the soil as received was 24.4 percent; the Atterberg limits were 32 for the liquid limit and 50 for the plastic limit. Air drying of the soil in the trays for several days resulted in the moisture dropping to about 15 percent for use in the pilot tests.

\section{BENCH-SCALE THERMAL DESORPTION TESTING PROGRAM}

Bench-scale testing was performed to confirm the effect of primary treatment variables on reduction of mercury. The tests also enabled an assessment of the characteristics of the residuals collected from the off-gas, which was an important step in preparing for the pilot tests. The treatment goals for the bench-scale tests were to reduce mercury to $10 \mathrm{mg} / \mathrm{kg}$; other constituents were not investigated.

The test program involved two types of thermal desorption systems: the static tray test and the rotary thermal apparatus (RTA). Testing began with the RTA because previous laboratory thermal desorption testing directed by Martin Marietta Energy Systems(3) provided a basis for selecting soil temperature and residence time values. The first series of RTA tests were to determine the effectiveness of $350^{\circ} \mathrm{C}$ for removing the mercury from the soil. The second series of tests were for investigating, at one residence time, the effect of air, steam, and nitrogen as different purge gases. The third series consisting of four tests was to determine the effect of particle size of the RTA feed on mercury removal. The feed soil was screened through wire cloth to produce a very coarse (0.5- to 1-inch) material. This material was treated in the RTA at the same conditions as the fine soil. The final series of RTA tests were conducted at selected conditions to fill in specific additional data needs.

The original test plan was modified because residual mercury concentrations were above the $10 \mathrm{mg} / \mathrm{kg}$ goal. Supplemental static tray screening tests were performed at a range of temperatures from $350^{\circ} \mathrm{C}$ to $650^{\circ} \mathrm{C}$. Ten tests were conducted; all used nitrogen as a purge gas, and nine used a time-at-temperature of 10 minutes.

\section{Bench-Scale Equipment Description}

Tray Desorption Test Apparatus - IT's "tray test" apparatus is identical to that described in EPA's 1992 guidance document(4). Typically, a 30- to 100-gram (g) sample of soil is spread in a thin (2-3 millimeter [mm]) layer in an open metal tray, which is placed in a standard muffle furnace. The temperature is rapidly adjusted to the desired desorption condition, while a purge gas is passed through the furnace interior. Temperatures of the soil layer and furnace interior adjacent to the tray are measured.

Rotary Thermal Apparatus - IT's RTA consists of a batch-loaded, indirectly heated rotating tube and associated offgas collection/treatment train. The rotating tube portion of the system is 12.7 centimeter $(\mathrm{cm})$ in diameter by 30.5 $\mathrm{cm}$ long; it rotates at five revolutions per minute $(\mathrm{rpm})$ and is externally heated with a custom-made electrical oven. Temperatures of the soil bed, the gas in the rotating cylinder, the oven, and off-gas system are recorded. The off- 
gases (purge gas, water vapor, and desorbed contaminants) from the cylinder exit through a heated quartz tube into a collection/treatment system that is configured according to the chemicals being desorbed and the data objectives of the testing. Typically, the off-gas first enters a heavy glass-walled spray tower scrubber where a caustic solution is recirculated through the spray tower. Uncondensed gases passing the spray tower are pulled through a carbon bed by an air-aspirated venturi pump before being discharged into a high-efficiency particulate air (HEPA)-filtered laboratory fume hood.

\section{Bench-Scale Thermal Desorption Results}

The results for the RTA tests are summarized in Table I. Only one test achieved a residual mercury concentration below $10 \mathrm{mg} / \mathrm{kg}$; this test had the longest residence time at temperature (1 hour). There was no significant difference between all the RTA results considering the typical variability to be expected in sampling and analytical accuracy for multiple tests from the same prepared soil batch. Residence time (between 10 and 20 minutes) and purge gas type did not have a definite influence on mercury removal. The oxygen concentration in the RTA vent gas from the first four experiments was higher than expected due to leakage through the seals, which were replaced; this variance is noted in the table $\left(^{*}\right)$. The use of nitrogen and steam purge reduced the oxygen level to approximately 2 to 5 percent for Tests 5 and 7. These results are typical of what could be achieved in a full-scale desorber with an inert gas purge.

TABLE I. Mercury Desorption RTA Test Summary

\begin{tabular}{|c|c|c|c|c|}
\hline RTA Test No & Time Soll is & $\begin{array}{l}\text { Soil Temperature. } \\
\text { (C) }\end{array}$ & Puirge Gas & Final $1 \mathrm{Hg}(\mathrm{mg} / \mathrm{kg})$ \\
\hline LEFPC-1 & 10 & 350 & Nitrogen* & 14.1 \\
\hline LEFPC-2 & 15 & 350 & Nitrogen* & 16.1 \\
\hline LEFPC-3 & 20 & 350 & Nitrogen* & 15.4 \\
\hline LEFPC-4 & 10 & 350 & Steam* & 13.3 \\
\hline LEFPC-5 & 10 & 350 & Nitrogen & 15.1 \\
\hline LEFPC-6 & 10 & 350 & Air & 12.1 \\
\hline LEFPC-7 & 10 & 350 & Steam & 11.4 \\
\hline LEFPC-8 & 60 & 350 & Air & 9.3 \\
\hline LEFPC-9** & 10 & 350 & Air & $7.4-8.7$ \\
\hline
\end{tabular}

*Seal leakage.

**Screened oversize, interior and exterior portions analyzed separately.

The tray test results were comparable to the RTA results. Residual mercury values ranged from 16.1 to $6.3 \mathrm{mg} / \mathrm{kg}$ over the range from 350 to $650^{\circ} \mathrm{C}$. All the results were below $10 \mathrm{mg} / \mathrm{kg}$ at temperatures above $400^{\circ} \mathrm{C}$. Increased temperature appeared to have a minor influence on residual mercury values, although a definite correlation could not be established due to the limited number of tests and the small range of mercury values. Increased residence time did not have a definite effect on treatment.

\section{PILOT-SCALE THERMAL DESORPTION TESTING PROGRAM}

The pilot program consisted of several tasks that were conducted separately. Initial objectives were as follows:

- Reduce mercury in the soil to below $10 \mathrm{mg} / \mathrm{kg}$.

- Demonstrate accountability for mercury throughout the process.

- Generate treated soil that is RCRA nonhazardous.

- Demonstrate the effectiveness of off-gas treatment. 
- Minimize residuals and treat any RCRA residuals.

- Evaluate soil material handling/preparation characteristics.

- Obtain sufficient engineering data to enable full-scale conceptual design and budgetary costing for use in feasibility study.

After the bench-scale desorption test results had been evaluated, the first objective was modified to demonstrate less than $20 \mathrm{mg} / \mathrm{kg}$ residual mercury. It was decided by the project team that it was preferable not to increase the desorption temperature substantially in order to achieve a residual mercury concentration of $10 \mathrm{mg} / \mathrm{kg}$ because this increase was expected to have a deleterious effect on the treated soil properties relative to replacement/reuse at the site.

\section{Desorption Pilot Test Plan}

A series of three pilot-scale tests were performed on LEFPC soil. The first test was to establish operating conditions for the desorber in order to obtain the throughput and treatment goals desired; soil residence time and temperature were selected based on the RTA results.

Test 2 was the official verification test, performed at $350^{\circ} \mathrm{C}$. The operating conditions developed during Test 1 were used to treat $330 \mathrm{~kg}$ of soil. Samples of soil feed, treated soil, desorber off-gas, scrubber liquids and solids, activated carbon, demister pad, and final vent gas were sampled and analyzed for various chemical parameters including mercury, selected other metals (e.g., cadmium, arsenic), VOCs, SVOCs, and PCBs. Treated soil was also analyzed for chlorodibenzodioxins/chlorodibenzofurans (CDD/CDF). Scrubber water was analyzed for total organic carbon and $\mathrm{pH}$. Off-gas and vent gas were also sampled and analyzed for particulate, acid gases, ammonia, oxygen and carbon dioxide.

Test 2 was also used to generate sufficient soil for two other types of subsequent testing. Forty-five kg of treated soil was used by the project team to evaluate its characteristics relative to being replaced in the floodplain (e.g., ability to support plant growth). Another portion of treated soil (197 kg) was used for back-end material handling tests.

Test 3 was performed at a higher desorption temperature of $600^{\circ} \mathrm{C}$; all other operating conditions were the same. This test was to demonstrate that the improved treatment to below $10 \mathrm{mg} / \mathrm{kg}$ mercury that was measured in the tray tests could be accomplished at the larger scale. The sampling and analysis program was similar to Test 2 with the exception of the gas sampling, which was limited to Orsat measurements of oxygen and carbon dioxide.

Table II lists the key process parameters for both the $350^{\circ} \mathrm{C}$ verification test and the $600^{\circ} \mathrm{C}$ test.

TABLE II. Pilot Desorber Operating Parameters

\begin{tabular}{|l|c|c|}
\hline \multicolumn{1}{|c|}{} & \multicolumn{2}{|c|}{ Range of Values } \\
\hline Larameter & Test $2-350^{\circ} \mathrm{C}$ & Test $3-600^{\circ} \mathrm{C}$ \\
\hline Soil temperature $\left({ }^{\circ} \mathrm{C}\right)$ & 325 to 390 & 578 to 616 \\
\hline Total feed soil weight $(\mathrm{kg})$ & 330 & 228 \\
\hline Soil feed rate $(\mathrm{kg} / \mathrm{hr})$ & 32 to 36 & 33 to 37 \\
\hline Soil residence time (total) (min) & 20 to 25 & 20 to 22 \\
\hline Soil residence time (at temperature) $(\mathrm{min})$ & 9 to 11 & 9 to 10 \\
\hline Purge gas flow (m/min) & 0.5 to 0.6 & 0.5 to 0.6 \\
\hline $\mathrm{O}_{2}$ in vent gas $(\%)$ & 16 to 18 & 15 to 17 \\
\hline $\mathrm{CO}_{2}$ in vent gas (\%) & 2.5 to 3.5 & 2.5 to 3.5 \\
\hline
\end{tabular}




\section{Materials Handling Tests}

The materials handling test program consisted of physical property measurements, feed chute drop tests, reagglomeration tests, and wet drag flight conveyor tests. The physical property tests were performed to assess handling characteristics such as adhesion, cohesion, and properties important to the design of soil preparation and feed systems. The "as received" soil was tested for initial moisture content and Atterberg limits.

Lime addition, calcium hydroxide, was also evaluated in an effort to produce a material that had less tendency to agglomerate and stick to surfaces. An addition of 1 and 2 percent lime by weight to two soil samples caused no significant change in Atterberg limits. Therefore, lime addition was not pursued as a method of preparing the soil feed for the thermal desorber.

The feed chute drop tests were designed to evaluate the tendency of the feed soil to stick to surfaces upon impact. The simplest method of introducing solids to a rotary desorber is by dropping the material onto an inclined chute, which directs it onto the soil bed. A pilot chute system was set up to test the effect of moisture content and chute angle on the degree of soil deposition on the chute surface. Moisture content was varied from 17 to 39 percent by adding water to the prepared soil batch; chute angle was varied from 45 to 71 degrees. A drop height of 13 feet was used for all tests; this was considered representative of a full-scale system.

The reagglomeration test was designed to observe any tendency of the soil to reagglomerate from tumbling and mixing in the rotating desorber. Soil was placed in a rotating drum and observed to see if a ball or "sausage" was formed. Soil moisture content was varied from 9 to 40 percent to determine at what point agglomeration began and at what point soil stuck to the rotating surface. Both phenomenon were considered detrimental to proper desorber performance.

To simulate a wet quench system with drag-flight conveyor, a slurry of treated soil from the $350^{\circ} \mathrm{C}$ verification test was prepared in a shallow tank. An inclined metal plate was placed in the tank at a 35 degree angle as a "dewatering beach"; the bottom section was submerged but the majority of its length was above the water level. A modified garden hoe was used to pull wet soil up the dewatering beach at a rate of 3.0 meters $(\mathrm{m})$ per minute. The angle of the beach and the drag rate and corresponding drainage time were selected to be representative of a full-scale system. The dewatered soil was stockpiled and weighed. The amount of soil retained by the "drag flight" and its moisture content were measured. The test was repeated until sufficient drained material was collected to form a pile for determination of the angle of repose before and after vibration. This characteristic is important in determining the practicality of stockpiling the wet soil prior to transport. The test was repeated using a longer drainage time (1 versus 0.3 minute). Two sets of additional tests were performed using higher water-to-soil ratios.

\section{Residuals Treatment Tests}

All liquid and solid residuals generated from the pilot testing were evaluated for RCRA hazardous characteristics (toxicity characteristic [TC]), both to determine if this was an issue for applying the technology and to enable return of these materials to Martin Marietta Energy Systems. If a residual had a constituent exceeding TC limits, it was treated in an appropriate manner based on initial bench-scale testing. For the liquid residuals, a treatment system was assembled consisting of a modified open-top drum, stir paddle, diaphragm pump, and specially made laboratory glass filtration vessel. Treatment chemicals were weighed, added to the tank, and blended manually. The $\mathrm{pH}$ was monitored continuously using a meter. The final settled solids "floc" was dewatered using a two section glass vacuum filtration vessel with filter media pad. Solid residuals from the desorption tests that contain mercury above toxicity characteristics leaching procedures (TCLP) limits were treated in the RTA or by acid rinsing in a small vessel.

\section{Pilot-Scale Thermal Desorption System}

The pilot testing of LEFPC soil was performed at IT's Environmental Technology Development Center in Oak Ridge, Tennessee. The pilot thermal desorption system has been used for dozens of thermal desorption tests beginning in 1985 $(5,6,7)$. In addition to thermal desorption tests, pilot-scale materials handling and residuals treatment testing was performed. This section describes the pilot facilities, with emphasis on the thermal desorption system.

IT's pilot thermal desorber process is essentially a scaled-down version of a full-scale system. The pilot system has in past studies given comparable results to bench-scale tests. The thermal desorber is a standard-design pilot calciner that 
consists of a continuously rotating tube partially enclosed with a gas-fired furnace shell. A flow diagram of the pilot system is shown in Figure 1.

The tube, constructed of Castalloy $\mathrm{H}-\mathrm{H}$, has a $16.5-\mathrm{cm}$ internal diameter and is $4.3 \mathrm{~m}$ long; the heated section is $2.3 \mathrm{~m}$ long. Small flights are placed at intervals within this tube to provide soil agitation. A stationary thermowell extends from the discharge end into the tube, with six thermocouples to monitor the soil temperature and three to monitor the gas temperature along the tube length. The soil residence time is a function of the soil bed volume and the soil feed rate. Soil bed volume is controlled by the rotational speed and inclination of the desorber tube. The soil feed rate is controlled by the rotational speed of a feed-screw conveyor. The furnace is a refractory-lined chamber with 14 equally spaced burners (propane) controlled by a standard burner control system with appropriate safety features. Burner firing rate is manually controlled to give the desired soil temperature profile.

The discharge end section of the desorber tube is enclosed by an air-cooled casing. Soil exits the desorber tube through a gas plenum/transition section and a rotary air-lock valve into a metal receiver can. Purge gas is introduced at a low flow rate at the soil discharge end to help flush desorbed contaminant vapors and to maintain the proper atmosphere for the treatment process. The off-gas flows from a plenum at the soil feed end of the desorber containing the purge gas, volatilized contaminants and water, and some particulates. The off-gas is transferred through a short electrically-heated, insulated duct to the off-gas treatment system.

The off-gas treatment system was comprised of a hot cyclone, a spray scrubber with demister pad, a wet electrostatic precipitator (WESP), a chilled, noncontact condenser, a mist eliminator, a HEPA filter, a two-stage carbon adsorber, and an induced-draft fan.

\section{PILOT-SCALE TEST RESULTS - LEFPC SOIL}

\section{Thermal Desorption Results, Soil and Residuals}

A summary of the analytical results for mercury for both the $350^{\circ} \mathrm{C}$ and $600^{\circ} \mathrm{C}$ verification tests is given in Table III. Mercury was reduced to approximately 14 and $8 \mathrm{mg} / \mathrm{kg}$ for the $350^{\circ} \mathrm{C}$ and $600^{\circ} \mathrm{C}$ desorption temperatures, respectively. A series of temporally related feed and treated soil mercury results showed a relative standard deviation of 20 percent or less.

Table III shows the accountability/distribution for mercury throughout the system. Mercury was recovered primarily in the scrubber system; it concentrated in the scrubber solids and as elemental (liquid) mercury. During inspection of the off-gas treatment system after each test, elemental mercury was found throughout the scrubber system. The greatest amount was in the demister pad located on top of the scrubber. Elemental mercury was recovered from the demister pad and scrubber system at 12 and $13 \mathrm{~g}$ for the two tests, respectively. A small amount of floating semisolid material collected from the scrubber system tank for the $600^{\circ} \mathrm{C}$ test had a very high concentration of mercury. The elemental mercury values in the table represent the total combined liquid mercury isolated from all sources, including as a result of residuals treatment to achieve nonhazardous criteria. The carbon adsorber also collected some mercury. The data for $600^{\circ} \mathrm{C}$ test show less mercury collected in the scrubber and more collected in the carbon. In fact mercury broke through the primary adsorber, as indicated by the separate analysis of the primary and secondary carbon.

Approximately 45 percent of the total mercury ( 95 and $70 \mathrm{~g}$ ) calculated to be contained in the feed soil for Tests 2 and 3 , respectively, was accounted for in all the process output streams. Despite very thorough removal of all liquid and solid materials from the scrubber system, the accountability was low, presumably due to the size (surface area) and complexity of the pilot system and the tendency of the condensed mercury to spread and adhere to surfaces.

Organics found in the feed soil (PAHs and PCBs) were reduced in the treated soils to below the analytical method detection limit. Several other SVOCs, mostly tentatively identified compounds (TIC), were found in the treated soil from the $350^{\circ} \mathrm{C}$ test at concentrations below $1 \mathrm{mg} / \mathrm{kg}$. For the $600^{\circ} \mathrm{C}$ test, the only organic compound detected in the 
TABLE III. Mercury Distribution and Accountability for Pilot Tests

\begin{tabular}{|c|c|c|c|c|}
\hline \multirow{2}{*}{ Sample location } & \multicolumn{2}{|c|}{$\mathrm{l}$ (Test $2-350^{\circ} \mathrm{C}$} & \multicolumn{2}{|c|}{ - Test $3=600^{\circ} \mathrm{C}$} \\
\hline & $\begin{array}{l}\mathrm{Hg} \mathrm{Conc} / \\
(\mathrm{mg} / \mathrm{kg})\end{array}$ & $\begin{array}{l}\text { Hg Mass as \%od } \\
\text { Total Hg.Jn Feed }\end{array}$ & $\begin{array}{l}\text { Hg Conc } \\
\text { (mgdkg) }\end{array}$ & $\begin{array}{l}\mathrm{Hg} \text { Mass as \% of } \\
\text { Total Hg In Feed }\end{array}$ \\
\hline Feed soil & 290 & 100.00 & 290 & 100.00 \\
\hline Scrubber solids & 3925 & 24.69 & 2930 & 16.08 \\
\hline Recovered elemental Hg & 100 & 12.54 & 100 & 19.92 \\
\hline Treated soil & 14.6 & 3.82 & 8.2 & 2.05 \\
\hline Scrubber float solids & -- & 0 & 15300 & 0.72 \\
\hline Scrubber liquid & 7.6 & 0.90 & 2.3 & 0.07 \\
\hline Carbon adsorber & 185 & 0.58 & $650 / 0.1^{*}$ & 2.6 \\
\hline Cyclone solids & 35.4 & 0.01 & 6.8 & 0.1 \\
\hline Brinks demister & 4.9 & 0.01 & 829 & 1.68 \\
\hline WESP receiver & 0.6 & 0.03 & 24 & 1.72 \\
\hline Condenser receiver & 4.3 & 0.01 & 13 & 0.02 \\
\hline HEPA filter & 1.9 & $<0.01$ & 26 & 0.06 \\
\hline Vent gas & - & $<0.01$ & - & $<0.01$ \\
\hline Sum of $\mathrm{Hg}$ & -- & 42.56 & -- & 43.50 \\
\hline
\end{tabular}

*Analysis of primary/secondary adsorbers

treated soil was naphthalene at 39 micrograms per kilogram $(\mu \mathrm{g} / \mathrm{kg}$ ) (parts per billion). Various CDD/CDF were detected at levels under $1 \mu \mathrm{g} / \mathrm{kg}$ for the treated soil from the $350^{\circ} \mathrm{C}$ test; only octachlorodibenzodioxin was detected at less than $1 \mu \mathrm{g} / \mathrm{kg}$, for the $600^{\circ} \mathrm{C}$ treated soil. Treated soil from both tests passed TCLP for metals and organics.

The organic analytical data for the residuals showed PAHs and PCBs, as well as VOCs and SVOCs, that were not detected in the untreated soil. The type of compounds found in the residuals were comparable to those measured in the off-gas sampling, which is discussed in the next section, except for a few notable exceptions. Highly volatile compounds, such as chloromethane, were not detected in the residuals; pyridine, which was found at relatively high levels in the scrubber liquid and sludge, was not found in the off-gas analysis. The type of organics present in the residuals from the $600^{\circ} \mathrm{C}$ test were very similar to those found in the $350^{\circ} \mathrm{C}$ test, but the concentrations were higher. For the $350^{\circ} \mathrm{C}$ test, PCBs concentrated in the scrubber sludge to slightly greater than $50 \mathrm{mg} / \mathrm{kg}$, the TSCA limit; the PCB content was lower in the sludge from the $600^{\circ} \mathrm{C}$ test.

Less soluble compounds tended to concentrate in the scrubber sludge, whereas the phenols and pyridine distributed between the scrubber liquid and sludge. The activated carbon from both tests had VOCs, particularly the more volatile ones; naphthalene and several other lower molecular weight SVOCs were also found in the carbon from the $600^{\circ} \mathrm{C}$ test.

Total uranium and gross alpha/beta values measured for the untreated soil and various residuals indicate that there is no significant partitioning of radionuclides to any residual. The residuals are generally lower in uranium than the untreated soil. However, final determination of the potential for concentration of radioactive constituents in certain residuals could not be made from the limited results of this testing. 


\section{Off-Gas Treatment Results}

The off-gas (downstream of the cyclone) and final vent gas were sampled and analyzed to demonstrate the removal efficiency of the off-gas treatment system. Parameters that were evaluated include particulate; metals (mercury, arsenic, cadmium, and uranium); volatile and semivolatile organics; acid gases and ammonia; and for the vent gas only, oxygen, carbon monoxide, and carbon dioxide.

The total particulate loading from the desorber, determined from combining the mass of solids collected in the hot cyclone and scrubber liquid, represented approximately 1.5 percent of the soil feed; the majority of these solids collected in the scrubber.

VOC results for the off-gas indicate aromatic hydrocarbons, several aliphatic hydrocarbons (paraffins and olefins), several oxygenated paraffins (e.g., ketones), and furans. In addition, chlorinated hydrocarbons and carbon disulfide were detected. The most significant VOCs included benzene, toluene, acetone, 2-butanone, furan, 2-methyl furan, chloromethane, and carbon disulfide.

A large number of SVOCs were found in the off-gas, including phenolics, PAHs, and other cyclic hydrocarbons and some oxygenated paraffins (e.g., aldehydes). The total SVOC content was similar to the total VOC content. Phenol and methyl phenols contributed most of the confirmed SVOCs; the major TIC contributed approximately 40 percent of the total SVOCs. This data corresponds with the residuals data, except no pyridine was detected in the off-gas.

The off-gas contained only trace levels of most acid gases based on analysis of anions. However, ammonia was found in the off-gas at a relatively high level $\left(790 \mu \mathrm{g} / \mathrm{m}^{3}\right)$. The source of the ammonia was not determined. It could have originated from decomposition of nitrogenous soil organic matter.

The off-gas treatment system proved very effective in controlling all parameters, which was expected because of the variety and number of control devices. Table IV shows the off-gas and vent gas concentrations, as well as overall removal efficiency for each parameter.

TABLE IV. Removal Efficiency of the Off-Gas Treatment System

\begin{tabular}{|c|c|c|c|}
\hline Parameter & $\begin{array}{l}\text { off-Gas Concentration } \\
\quad\left(\mathrm{mg} / \mathrm{m}^{3}\right)\end{array}$ & $\begin{array}{c}\text { Yent Gas Concentration } \\
\text { (mg/m }\end{array}$ & $\begin{array}{l}\text { RemovalEfficiency } \\
\quad(\%) \quad \ldots\end{array}$ \\
\hline Particulates & 5608 & $<1$ & $>99.98$ \\
\hline Mercury & 229 & $\mathrm{ND} *(0.0002)$ & $>99.999$ \\
\hline Other metals & 4.6 & 0.003 & 99.93 \\
\hline VOC & 105 & 1.1 & 98.9 \\
\hline SVOC & 81 & 0.13 & 99.8 \\
\hline Acid gases & 46 & 0.63 & 98.6 \\
\hline Ammonia & 790 & $\mathrm{ND}(0.02)$ & $>99.99$ \\
\hline
\end{tabular}

*ND - Not detected

\section{Materials Handling Test Results}

The data indicates that as the moisture content of soil approaches the plastic limit (32 percent) of the untreated soil, the soil tends to fail both the drop test and agglomeration test. To avoid difficulties, the moisture content should be maintained at less than 25 percent; excavated soil having higher moisture could be partially air dried or blended with dryer material in the storage area. 
The back-end materials handling data demonstrated that the treated soil can be processed effectively using a drag-flight conveyor and can be stockpiled.

\section{Residuals Treatment Results}

The purpose of the residuals treatment was to ensure that none of the residuals were classified as a RCRA hazardous waste. The aqueous scrubber solution from the verification pilot tests exceeded TC limits for mercury and pyridine. The liquid was treated using chelation/chemical precipitation followed by carbon adsorption. Mercury in the scrubber liquid was reduced from several milligrams per liter $(\mathrm{mg} / \mathrm{L})$ to $0.008 \mathrm{mg} / \mathrm{L}$, well below the TC limit of $0.2 \mathrm{mg} / \mathrm{L}$. Pyridine was reduced from $120 \mathrm{mg} / \mathrm{L}$ to less than $1 \mathrm{mg} / \mathrm{L}$. Other aqueous residuals which were above the mercury TC limit were also successfully treated by chelation/chemical precipitation.

The sludge collected in the filter bags from all three pilot tests was air dried and placed in the RTA for thermal desorption treatment. Mercury was not detected in the TCLP extract of the treated solids; the total mercury had been reduced to $20 \mathrm{mg} / \mathrm{kg}$. The precipitated and dewatered solids generated from treatment of the scrubber liquids and decon water were composited and successfully treated in the RTA in the same manner.

The liquid elemental mercury (approximately $30 \mathrm{~g}$ ) collected from all sources was combined and treated with powdered zinc and powdered sulfur to produce an amalgam. This mixture was then stabilized using cement and water. The resulting TCLP mercury concentration was $0.008 \mathrm{mg} / \mathrm{L}$.

The synthetic fabric filter bags, demister media, and HEPA filter media were treated by washing with dilute nitric acid which reduced the mercury (and other metals in the case of the HEPA) to below TC limits.

\section{ENGINEERING AND COST ASSESSMENT}

The information from the pilot tests was used to assess the application of a full-scale thermal desorption system to treat LEFPC soil. A preliminary process design was developed, which included an overall material and energy balance, list and sizing of major equipment, and operating requirements. The basis was 32 metric tons per hour ( 90 percent onstream factor) of soil containing $300 \mathrm{mg} / \mathrm{kg}$ mercury and 25 percent moisture. The facility scope included all process components, from desorber feed system to treated soil material handling system; residual treatment prior to off-site disposal and effluent treatment and recycle was included.

The budgetary capital cost estimate was $\$ 12.3$ million (plus or minus 25 percent), with the desorber and off-gas system representing 58 percent of this total. Estimated major operating and maintenance costs including labor, utilities, consumables, maintenance materials, and off-site disposal represent a total processing cost of $\$ 45$ per metric ton. Other remediation costs, including excavation, transport, replacement, and other site activities, would be additional to this processing cost.

\section{CONCLUSIONS}

The LEFPC pilot testing demonstrated that thermal desorption is applicable to remediate the LEFPC floodplain soils. The process removed mercury from $300 \mathrm{mg} / \mathrm{kg}$ to below $15 \mathrm{mg} / \mathrm{kg}$ at treatment conditions of $350^{\circ} \mathrm{C}$ for 10 minutes at temperature, and to below $10 \mathrm{mg} / \mathrm{kg}$ at $600^{\circ} \mathrm{C}$ for 10 minutes at temperature. The desorber off-gas can be cleaned using a series of conventional air pollution control devices to approximately 99 percent or greater removal of all measured contaminants. Mercury emissions were controlled by greater than 99.99 percent. More than 85 percent of the mercury recovered was collected in the wet scrubber, with approximately 60 percent of this isolated as elemental liquid mercury. Several process residuals were generated that could be RCRA hazardous. These residuals can be treated using conventional processes to render them nonhazardous. The capital cost of a high capacity desorption facility is estimated to be $\$ 12.3$ million with operating costs of $\$ 45$ per metric ton. 


\section{REFERENCES}

1. Thermal Desorption, Innovative Site Remediation Technology, prepared by WASTECHß, W.C. Anderson, Ed. (1993).

2. ALPERIN, E.S., A. GROEN, and R.D. FOX, "Treatment of Mixed Waste Sludge," presented at 84th Annual Meeting of the Air and Waste Management Association, Vancouver, B.C. (June 16-21, 1991).

3. U.S. DEPARTMENT OF ENERGY, "Draft Treatability Study Report for Mercury in East Fork Poplar Creek, Oak Ridge, Tennessee," prepared by Radian Corp. (February 1993).

4. U.S. ENVIRONMENTAL PROTECTION AGENCY, "Guide to Conducting Treatability Studies Under CERCLA: Thermal Desorption Remedy Selection - Interim Guidance," 540/R-92/074A, RREL Cincinnati, and OERR and OSWER, Washington, DC (April 1992).

5. HELSEL, R., E. ALPERIN, T. GEISLER, A. GROEN, R. FOX, T.L. STODDART, and H.D. WILLIAMS, "Technology Demonstration of a Thermal Desorption/UV Photolysis process for Decontaminating Soils Containing Herbicide Orange," Solving Hazardous Waste Problems - Learning from Dioxins, American Chemical Society Symposium Series 338 (1987).

6. FOX, R.D., E.S. ALPERIN, and H.H. HULS, "Thermal Treatment for the Removal of PCBs and Other Organics From Soil, Environmental Progress 10:1 (1991).

7. HELSEL, R.W., E. ALPERIN, and A. GROEN, "Engineering-Scale Demonstration of Thermal Desorption Technology for Manufactured Gas Plant Site Soils," HWRIC RR-038, Hazardous Waste Research and Information Center, Savoy (1989). 


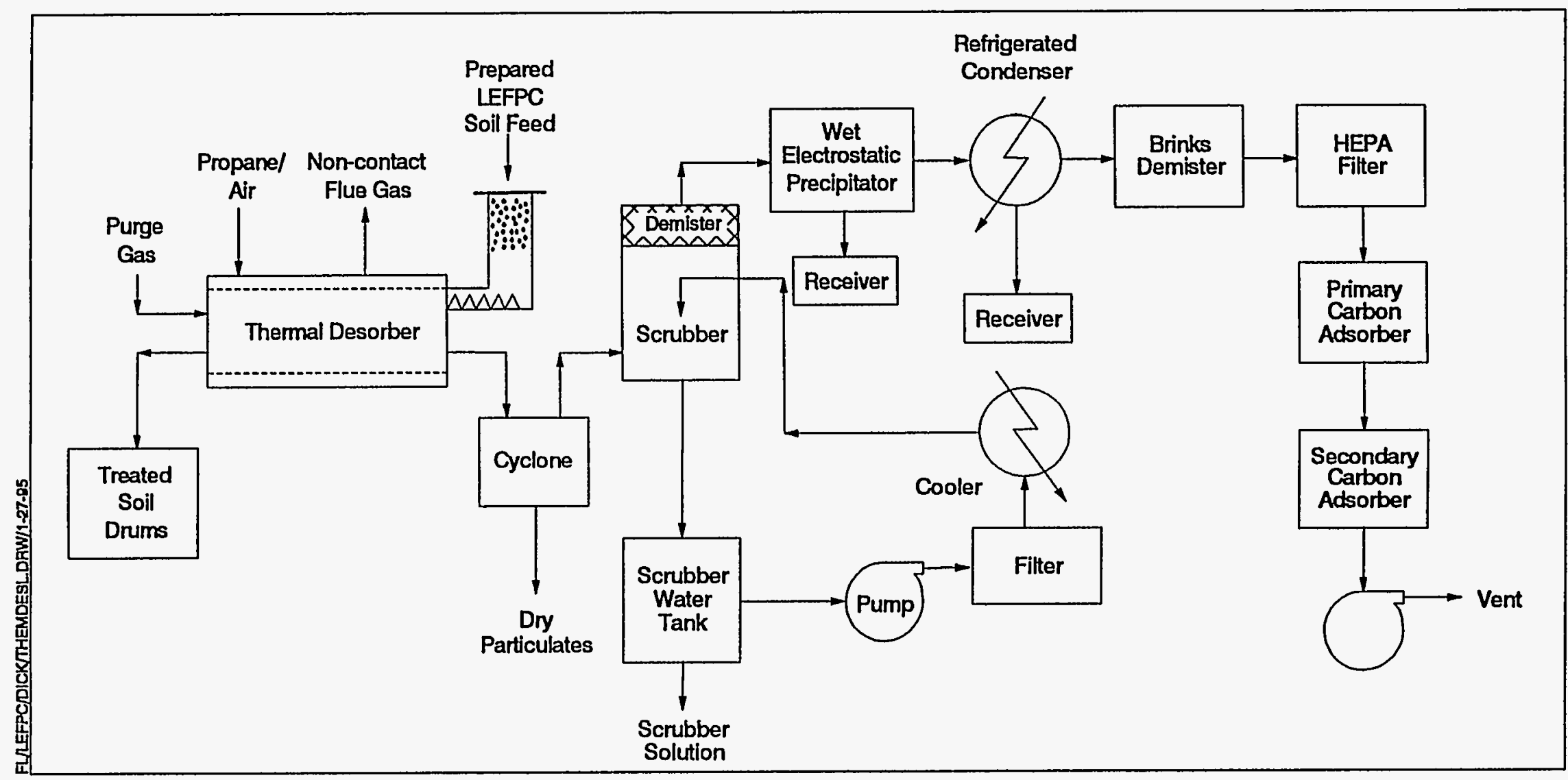

Fig. 1 - IT Pilot-Scale Thermal Desorber System 